University of Nebraska - Lincoln

DigitalCommons@University of Nebraska - Lincoln

USDA National Wildlife Research Center - Staff Publications
U.S. Department of Agriculture: Animal and Plant Health Inspection Service

2017

\title{
Ecological Potential for Rabies Virus Transmission via Scavenging of Dead Bats by Mesocarnivores
}

Tad C. Theimer

Northern Arizona University, theimer@nau.edu

Annie C. Dyer

Northern Arizona University

Brian W. Keeley

Northern Arizona University

Amy T. Gilbert

USDA/APHIS/WS National Wildlife Research Center, Amy.T.Gilbert@aphis.usda.gov

David L. Bergman

USDA APHIS Wildlife Services

Follow this and additional works at: https://digitalcommons.unl.edu/icwdm_usdanwrc

Part of the Life Sciences Commons

Theimer, Tad C.; Dyer, Annie C.; Keeley, Brian W.; Gilbert, Amy T.; and Bergman, David L., "Ecological Potential for Rabies Virus Transmission via Scavenging of Dead Bats by Mesocarnivores" (2017). USDA National Wildlife Research Center - Staff Publications. 1935.

https://digitalcommons.unl.edu/icwdm_usdanwrc/1935

This Article is brought to you for free and open access by the U.S. Department of Agriculture: Animal and Plant Health Inspection Service at DigitalCommons@University of Nebraska - Lincoln. It has been accepted for inclusion in USDA National Wildlife Research Center - Staff Publications by an authorized administrator of DigitalCommons@University of Nebraska - Lincoln. 


\section{Ecological Potential for Rabies Virus Transmission via Scavenging of Dead Bats by Mesocarnivores}

Tad C. Theimer, ${ }^{1,4}$ Annie C. Dyer, ${ }^{1}$ Brian W. Keeley, ${ }^{1}$ Amy T. Gilbert, ${ }^{2}$ and David L. Bergman ${ }^{3} \quad{ }^{1} D^{2}$ artment of Biological Sciences, Northern Arizona University, NAU Box 5640, Flagstaff, Arizona 86011, USA; ${ }^{2}$ National Wildlife Research Center, US Department of Agriculture, Animal and Plant Health Inspection Service, Wildlife Services, 4101 LaPorte Avenue, Fort Collins, Colorado 80521, USA; ${ }^{3}$ US Department of Agriculture, Animal and Plant Health Inspection Service, Wildlife Services, 8836 N 23 Avenue, Suite 2, Phoenix, Arizona 85021, USA; ${ }^{4}$ Corresponding author (email: tad. theimer@nau.edu)

ABSTRACT: Multiple species of bats are reservoirs of rabies virus in the Americas and are occasionally the source of spillover infections into mesocarnivore species. Although rabies transmission generally is assumed to occur via bite, laboratory studies have demonstrated the potential for rabies transmission via ingestion of rabid animals. We investigated the ecological potential for this mode of transmission by assessing mesocarnivore scavenging behavior of dead bats in suburban habitats of Flagstaff, Arizona, US. In autumn 2013, summer 2014, and autumn 2015, we placed 104 rabies-negative bat carcasses either near buildings, in wildland areas, or in residential yards and then monitored them with trail cameras for 5 d. Overall, $52(50 \%)$ bat carcasses were scavenged, with $39(75 \%)$ of those scavenged by striped skunks (Mephitis mephitis). Within our study area, striped skunks had a higher ecological potential to contract rabies via ingestion of bat carcasses compared to other mesocarnivore species, due both to a greater number of encounters and a higher probability of ingestion per encounter $(91 \%)$, and they were significantly more likely to approach bat carcasses in yards than in wildland areas. Raccoons (Procyon lotor) and gray foxes (Urocyon cinereoargenteus) had fewer encounters (nine and 13, respectively) and lower probability of ingesting bats $(33 \%$ and $8 \%$, respectively).

Key words: Bat, Mephitis mephitis, Procyon lotor, rabies, scavenging, skunk, Urocyon cinereoargenteus.

Multiple species of bats are reservoirs of rabies and other lyssaviruses (Patyk et al. 2012; Banyard et al. 2014) and represent a public health risk because of the potential to transmit the rabies virus (RV) to humans and other animals (Shankar et al. 2006; Kuzmin et al. 2012). Although the principal mode of RV transmission occurs via bite, animals feeding on infected carcasses can also contract the disease. For example, six of 18 striped skunks (Mephitis mephitis) died of rabies after eating rabid mice infected with RV isolated from silver-haired bats (Lasionycteris noctivagans; Bell and Moore 1971), whereas 10 of 13 skunks died of rabies after eating rabid mice infected with the challenge virus strain of RV (Ramsden and Johnson 1975). These studies suggest that scavenging of dead bats may be a potential means for mesocarnivores to contract rabies. Bats have been found in the scats of a variety of carnivores that forage near bat caves (Winkler and Adams 1972; McAlpine et al. 2011), and mesocarnivores such as bobcats (Felis rufus) and domestic cats (Felis catus) have been documented actively hunting bats (Wroe and Wroe 1982; Delpietro et al. 1994), but no studies have examined the potential for bat carcasses to be scavenged by wild and domestic carnivores in suburban areas where human and pet contact with wildlife may be greatest.

Our study focused on suburban neighborhoods of Flagstaff, Arizona, US (population, 65,000 ; elevation, $2,170 \mathrm{~m}$; $35^{\circ} 11^{\prime} 57^{\prime \prime} \mathrm{N}$, $111^{\circ} 37^{\prime} 52^{\prime \prime} \mathrm{W}$ ) where a rabies outbreak in gray foxes (Urocyon cinereoargenteus) and three separate outbreaks in striped skunks were associated with a big brown bat (Eptesicus fuscus) RV variant (Leslie et al. 2006; Kuzmin et al. 2012). Initially characterized as a host-shift from bats to striped skunks (Leslie et al. 2006), subsequent analyses indicated that the big brown bat variant was introduced to skunks and foxes independently during each outbreak (Kuzmin et al. 2012).

To assess the ecologic potential for rabies transmission via scavenging of dead bats by 
TABLE 1. The total number of bat carcasses deployed by season and year in suburban and wildland areas of Flagstaff, Arizona, USA from 2013 to 2015, and the number of times carcasses were approached/number of times the carcasses were removed or ingested by striped skunk (Mephitis mephitis), raccoon (Procyon lotor), gray fox (Urocyon cinereoargenteus), domestic cat (Felis catus), domestic dog (Canis lupus familiaris), coyote (Canis latrans), and other scavengers. "Other" included American Crow (Corvus brachyrhynchos) with one removal and rock squirrel (Otospermophilus variegatus) with five removals; cliff chipmunks (Eutamias dorsalis), graycollared chipmunks (Eutamias cinericollis), deer mice (Peromyscus maniculatus), pinyon mice (Peromyscus truei), and white-throated woodrats (Neotoma albigula) also approached baits.

\begin{tabular}{lccccccccc}
\hline & & & \multicolumn{5}{c}{ Animals approaching baits/animals removing baits } \\
\cline { 7 - 10 } Season & Year & $\begin{array}{c}n \text { Carcasses } \\
\text { deployed }\end{array}$ & Skunk & Raccoon & Gray fox & Cat & Dog & Coyote & Other \\
\hline \multirow{2}{*}{ Autumn } & 2013 & 12 & $4 / 3$ & $0 / 0$ & $3 / 0$ & $2 / 0$ & $1 / 0$ & $1 / 0$ & $7 / 0$ \\
Summer & 2014 & 63 & $29 / 27$ & $7 / 2$ & $6 / 0$ & $29 / 2$ & $3 / 0$ & $1 / 0$ & $20 / 2$ \\
Autumn & 2015 & 29 & $10 / 9$ & $2 / 1$ & $4 / 1$ & $4 / 1$ & $1 / 0$ & $0 / 0$ & $13 / 4$ \\
& All & 104 & $43 / 39$ & $9 / 3$ & $13 / 1$ & $35 / 3$ & $5 / 0$ & $2 / 0$ & $40 / 6$ \\
\hline
\end{tabular}

mesocarnivores, we placed a single carcass of a bat on the ground at each of 104 locations in the three neighborhoods of Flagstaff that had experienced rabies outbreaks. We monitored carcasses by using infrared, motion-sensitive trail cameras (Cuddeback, Non-Typical, Green Bay, Wisconsin, USA) for $5 \mathrm{~d}$. All bats were tested and diagnosed negative for rabies before they were deployed. We placed bats at three types of locations: 1) within $1 \mathrm{~m}$ of a shed or house (i.e., where bats might fall from a roost under eaves or facia boards), 2) in residential yards, and 3) in wildland areas within or on the edge of the suburban matrix. At the end of the 5-d test period, all unscavenged bat carcasses were recovered and destroyed. In total, we deployed 63 Brazilian free-tailed bats (Tadarida brasiliensis), 26 big brown bats, and 13 bats in the genus Myotis that represented multiple species. Species of bats were deployed across location types randomly.

Over both years, 52 of 104 bats in total were scavenged (Table 1). A chi-square test revealed that the six mesocarnivores did not approach bat carcasses with equal probability $\left(\chi^{2}=81, \mathrm{df}=5, P=0.000\right)$. Striped skunks visited bat carcasses most frequently (43/104, 41\%) and took bats in $91 \%$ of encounters. Domestic cats were the second most frequent visitor, approaching bats 35 times but removing or eating bats only three times (9\%). Raccoons (Procyon lotor), gray foxes, coyotes (Canis latrans), and domestic dogs (Canis lupus familiaris) approached bats less often and took bats less frequently. A chi-square test indicated that striped skunks approached bats significantly more in yards, significantly less in wildlands, and as often as expected near buildings based on the number of bats placed in each location $\left(\chi^{2}=12.3, \mathrm{df}=2, \quad P=0.002\right)$. Sample size was too low for statistical comparisons for other mesocarnivores, but all gray fox approaches of bats were in wildland areas, whereas $67 \%$ of approaches by cats and $78 \%$ of approaches by raccoons were in either yards or near buildings. Overall, we documented that in suburban Flagstaff, striped skunks were the most likely mesocarnivore to encounter and ingest dead bats and that those encounters were more likely in yards and near buildings than in wildland areas.

Our findings contrast with several other studies that have reported the relative importance of bats in the diet of mesocarnivores or that have investigated scavenging behavior of mesocarnivores by using rodents as prey. Only $25 \%$ of skunk scats collected from caves where bats roosted in large numbers in the southwestern US contained bat remains, whereas $75 \%$ of fox scats and $87 \%$ of raccoon scats did (Winkler and Adams 1972). Likewise, McAlpine et al. (2011) estimated that raccoons consumed >3,000 Myotis spp. from a winter hibernacula cave in New Brunswick, Canada, 
during an outbreak of white-nose syndrome. One caveat of diet studies based on scat analyses is that scavenged prey items cannot be distinguished from those taken alive (DeVault et al. 2003). More comparable to our study are studies that examined scavenging of mouse and rat carcasses. Two of these studies, in rural Indiana, found raccoons were the most important scavenger of rodent carcasses, followed by opossums (Didelphis virginianus) and gray foxes, with striped skunks taking rodent carcasses only once at each site (DeVault and Rhodes 2002; DeVault et al. 2011), the opposite of the pattern we documented. Another study using rodent carcasses in the UK, found Common Crows (Corvus corax) and Eurasian Magpies (Pica pica) were important scavengers of mouse carcasses (Inger et al. 2016). Although Ravens (Corvus corax) and American Crows (Corvus brachyrhynchos) are common in Flagstaff, we recorded a crow taking a bat only once. Finally, squirrels have been reported scavenging at low levels in other studies (DeVault and Rhodes 2002; DeVault et al. 2011), but in our study rock squirrels (Otospermophilus variegatus), the most common ground squirrel in urban Flagstaff, took more bat carcasses than raccoons, domestic cats, or gray foxes. These comparisons underscore that the ecologic potential for disease transmission via scavenging is likely to vary depending upon scavenger community composition and relative abundance.

We did not estimate density of mesocarnivores in our study; however, based on population estimates from other studies in Flagstaff (Maestas et al. 2012), we estimate skunk densities in our study areas to range between 15 and 30 skunks $/ \mathrm{km}^{2}$. Given the lower encounter rate we documented for raccoons and gray foxes in this study and in others in urban Flagstaff (Theimer et al. 2015), abundances of these two species would be much lower. In contrast, skunk densities in urban Toronto, Canada, were reported as 6$13 / \mathrm{km}^{2}$, whereas raccoon densities in those areas were estimated to be $37-94 / \mathrm{km}^{2}$ (Broadfoot et al. 2001). How regional differences in relative abundances of mesocarnivores change the ecologic potential for transmission of disease via scavenging of bat carcasses remains an important question.

Many scavenging studies done elsewhere (e.g., DeVault et al. 2011; Inger et al. 2016) relied on rodent carcasses because they are more readily available than bat carcasses, but whether mesocarnivores respond differently to bat versus rodent carcasses has not been tested. Within bats, species may also differ in relative attractiveness to mesocarnivores. We noted that free-tailed bats had a strong odor lacking in the other bat species we used. We lacked the sample sizes to test for differences in acceptability among bat species, but anecdotally noted that free-tailed bats seemed to be taken at the same rates as other bat species. Still, the question remains to be rigorously tested.

Overall, our study documented an ecologic potential for transmission of disease from dead bats to mesocarnivores, especially striped skunks, via scavenging. Given that many bat species roost in single-family homes (O’Shea et al. 2011), sick or dying bats falling from these roosts are likely to land near buildings or in yards where skunk encounters with bat carcasses were more likely. Therefore, reducing availability of human-provided dens and food sources for skunks may decrease potential for bat-to-skunk RV transmission either via scavenging or through other interactions. Skunk dens in and around homes can be sealed after animals are removed using a combination of wire screening, rocks, or concrete, and we found homeowners receptive to making modifications to exclude skunks. We encourage pest control companies to include permanent exclusion as the preferred option over trapping and removing skunks, as we noted that skunk den sites are rapidly recolonized. Finally, the peridomestic nature of skunks, bats, and other rabies reservoir hosts emphasizes the need to maintain current rabies vaccinations in pets and proper reporting of potential human or pet exposures to RV.

We thank Laura E. Robinson (Texas Department of State Health Services), Darren Wostenberg (National Wildlife Research Cen- 
ter), and Dick Bowen (Colorado State University) for testing and providing bat carcasses. This work was approved under Northern Arizona University Institutional Animal Care and Use Committee Protocol 11-002-R1 to T.C.T. A.C.D. was supported through a National Science Foundation Undergraduate Research and Mentoring in the Biological Sciences program at Northern Arizona University.

\section{LITERATURE CITED}

Banyard AC, Evans JS, Luo TR, Fooks AR. 2014. Lyssaviruses and bats: Emergence and zoonotic threat. Viruses 6:2974-2990.

Bell JF, Moore GJ. 1971. Susceptibility of carnivora to rabies virus administered orally. Am J Epidemiol 93: 176-182.

Broadfoot JD, Rosatte RC, O’Leary DT. 2001. Raccoon and skunk population models for urban disease control planning in Ontario, Canada. Ecol Appl 11: 295-303.

Delpietro H, Konolsaisen F, Marchevsky N, Russo G. 1994. Domestic cat predation on vampire bats (Desmodus rotundus) while foraging on goats, pigs, cows and human beings. Appl Anim Behav Sci 39: 141-150.

DeVault TL, Olson ZH, Beasley JC, Rhodes OE Jr. 2011. Mesopredators dominate competition for carrion in an agricultural landscape. Basic Appl Ecol 12:268274.

DeVault TL, Rhodes OE. 2002. Identification of vertebrate scavengers of small mammal carcasses in a forested landscape. Acta Theriol 41:185-192.

DeVault TL, Rhodes OE Jr, Shivik JA. 2003. Scavenging by vertebrates: Behavioral, ecological, and evolutionary perspectives on an important energy transfer pathway in terrestrial ecosystems. Oikos 102:225234.

Inger R, Cox DTC, Per E, Norton BA, Gaston KJ. 2016. Ecological role of vertebrate scavengers in urban ecosystems in the UK. Ecol Evol 6:7015-7023.

Kuzmin IV, Shi M, Orciari LA, Yager PA, Velasco-Villa A, Kuzmina NA, Streicker DG, Bergman DL, Rupprecht CE. 2012. Molecular inferences suggest multiple host shifts of rabies viruses from bats to mesocarnivores in Arizona during 2001-2009. PLoS Pathog 8:e1002786.

Leslie MJ, Messenger S, Rohde RE, Smith J, Cheshier R, Hanlon C, Rupprecht CE. 2006. Bat-associated rabies virus in skunks. Emerg Infect Dis 12:12741277.

Maestas JM, Theimer TC, Hausig KM, Bergman DL. 2012. Striped skunk relative abundance in Flagstaff, Arizona: Implications for rabies spread and the current TVR program. In: Proceedings of the 25th vertebrate pest conference, Monterey, California, 6-9 March; University of California, Davis, California, pp. 267-270.

McAlpine DF, Vanderwolf KJ, Forbes GJ, Malloch D. 2011. Consumption of bats (Myotis spp.) by raccoons (Procyon lotor) during an outbreak of white-nose syndrome in New Brunswick, Canada: Implications for estimates of bat mortality. Can Field Nat 125:257260.

O'Shea TJ, Neubaum DJ, Neubaum MA, Cryan PM, Ellison LE, Stanley TR, Rupprecht CE, Pape WJ, Bowen RA. 2011. Bat ecology and public health surveillance for rabies in an urbanizing region of Colorado. Urban Ecosyst 14:665-697.

Patyk K, Turmelle A, Blanton JD, Rupprecht CE. 2012. Trends in national surveillance data for bat rabies in the United States: 2001-2009. Vector Borne Zoonotic Dis 12:666-673.

Ramsden RO, Johnston DH. 1975. Studies on the oral infectivity of rabies virus in carnivore. J Wildl Dis 11: 318-324.

Shankar V, Orciari LA, De Mattos C, Kuzmin IV, Pape WJ, O'Shea TJ, Rupprecht CE. 2006. Genetic divergence of rabies viruses from bat species of Colorado, USA. Vector Borne Zoonotic Dis 5:330 341.

Theimer TC, Clayton AC, Martinez A, Peterson DL, Bergman DL. 2015. Visitation rate and behavior of urban mesocarnivores differs in the presence of two common anthropogenic food sources. Urban Ecosyst 18:895-906.

Winkler WG, Adams DB. 1972. Utilization of southwestern bat caves by terrestrial carnivores. Am Midl Nat 87:191-200.

Wroe DM, Wroe S. 1982. Observation of bobcat predation on bats. J Mammal 63:682-682.

Submitted for publication 1 September 2016.

Accepted 9 November 2016. 